Section Editor

Robert C. Griggs, MD
Editors' Note: WriteClick this week centers on marijuana and stroke. Drs. Barber and Anderson report the results of their case-control study that demonstrated an adjusted odds ratio of 2.30 for recent cannabis exposure and stroke in younger ischemic stroke and TIA patients. They and author Brust agree on the need for more research and more comprehensive drug screening in stroke patients. Drs. Freeman and Louh describe a case of synthetic marijuana-induced seizures and encephalopathy. Authors Gooch et al. call for improved educational outreach on the risks of these compounds, which are proving to be more dangerous than the general public is inclined to believe. -Megan Alcauskas, MD, and Robert C. Griggs, MD

\section{SPICE, POT, AND STROKE}

Peter Alan Barber, Neil E. Anderson, Auckland, New Zealand: In his editorial, Dr. Brust ${ }^{1}$ suggested that there is skepticism regarding anecdotal reports of marijuana-related stroke because there are so few. In the accompanying article, Freeman et al. ${ }^{2}$ reported 2 healthy siblings presenting with ischemic stroke after smoking the schedule I synthetic cannabinoid "spice."

We conducted a case-control study of 160 younger ischemic stroke and TIA patients and 160 age-, sex-, and ethnicity-matched controls who were screened for cannabis use within 72 hours of hospital admission. ${ }^{3}$ Twenty-five (16\%) cases had positive cannabis screens, significantly increasing the number of patients previously reported. Thirteen $(8 \%)$ control participants had positive cannabis screens, which provides an adjusted odds ratio of 2.30 for cannabis exposure and stroke. An association independent of tobacco could not be confirmed as all but one of the stroke patients used tobacco.

Cannabis and its synthetic analogues are generally perceived as having few serious adverse effects, yet our data $^{3}$ and those reported by Freeman et al. ${ }^{2}$ suggest this may not be true. We agree that it is important for neurologists to be aware of a potential association between these agents and stroke. Furthermore, we also suggest that younger stroke and TIA patients should be screened for cannabis and synthetic cannabinoids, particularly if there are no other vascular risk factors. In addition, those with positive screens should be counseled against further use. The increasing decriminalization of cannabis for both medicinal and recreational use
WriteClick: Editor's Choice

and increased use of spice in the community also makes it imperative that further research is undertaken to further clarify these relationships.

Author Response: John C.M. Brust, New York: While stroke risk conferred by tobacco and alcohol is based on a multitude of epidemiologic studies, the risk conferred by illicit drugs is mostly anecdotal. Data like those provided by Barber et al. are overdue, and I hope future studies will be able to adjust for tobacco (which had a lower $p$ value than marijuana in the analysis by Barber et al.). My only disagreement with Barber et al. involves their recommendation to screen "younger stroke and TIA patients" for cannabis and synthetic cannabinoids. I would recommend screening for illicit drugsnot just cannabis-in any patient with a stroke. If cocaine is an indication, many baby boomers have never turned over a new leaf. Age in itself does not exclude substance abuse as contributory to a stroke.

(C) 2014 American Academy of Neurology

1. Brust JCM. Spice, pot, and stroke. Neurology 2013;81: 2064-2065.

2. Freeman MJ, Rose DZ, Myers MA, Gooch CL, Bozeman AC, Burgin WS. Ischemic stroke after use of the synthetic marijuana “spice." Neurology 2013;81:2090-2093.

3. Barber PA, Pridmore HM, Krishnamurthy V, et al. Cannabis, ischemic stroke, and transient ischemic attack: a casecontrol study. Stroke 2013;44:2327-2329.

\section{ISCHEMIC STROKE AFTER USE OF THE SYNTHETIC MARIJUANA "SPICE"}

William D. Freeman, Jacksonville, FL; Irene K. Louh, New York: We read with interest the article by Freeman et al. ${ }^{1}$ on synthetic marijuana (spice). It is important that physicians and the lay public know the hazards of this substance, since greater recognition will lead to better diagnosis and treatment. The diagnosis of spice encephalopathy with stroke or seizure ${ }^{1,2}$ can be challenging because it may mimic some aspects of serotonin syndrome and neuroleptic malignant syndrome and does not have a simple laboratory test to make the diagnosis compared to other drug screens. ${ }^{1,2}$ Therefore, this disorder requires a high index of suspicion in making the clinical diagnosis. We recently had a young man with a spice encephalopathy and seizure 
after smoking this substance. We found a small bag of synthetic cannabis and a small cigarette that had been smoked, which supported the diagnosis. Our patient improved over 36 hours with supportive care, IV saline, and some intermittent low-dose lorazepam. The authors thank the authors for their case that also outlines the role of this substance in young patients with stroke. Spice use should also be considered in patients who mimic the triad of serotonin-like syndrome, like findings of autonomic (tachycardia, hypertension), neuromuscular (asterixis or myoclonus), and CNS (seizures, encephalopathy) findings.

Author Response: Clifton L. Gooch, Melissa J. Freeman, David Z. Rose, W. Scott Burgin, Tampa, FL: The authors thank Drs. Freeman and Louh for the interest in our article ${ }^{1}$ and for describing their patient with spice-induced seizure and encephalopathy. Their case report emphasizes the broadening spectrum of neurologic injury associated with synthetic marijuana, which is likely to expand as greater varieties and numbers of these compounds appear. ${ }^{2}$ Increasing vigilance on the part of first responders, emergency center personnel, neurologists, and other health care providers, and increasing education of the lay public on the potential risks of these agents, is paramount. They are often considered by naive consumers to be safe (due to their conceptual association with cannabis) and are frequently marketed in colorful, trendy packaging designed to give an air of commercial legitimacy and to attract the attention of adolescents and young adults. Public health agencies, schools, and clinics should expeditiously incorporate information highlighting the dangers of these compounds into their campaign materials, and governmental authorities should consider targeted legislation designed to curb their distribution and sale.

(C) 2014 American Academy of Neurology

1. Freeman MJ, Rose DZ, Myers MA, et al. Ischemic stroke after use of the synthetic marijuana "spice." Neurology 2013;81:2090-2093.

2. Gunderson EW. Synthetic cannabinoids: a new frontier of designer drugs. Ann Intern Med 2013;159:563-564.

\section{CORRECTIONS}

Long-term safety and effectiveness of natalizumab redosing and treatment in the STRATA MS Study

In the article "Long-term safety and effectiveness of natalizumab redosing and treatment in the STRATA MS Study" by P. O'Connor et al. (Neurology ${ }^{\circledR}$ 2014;83:78-86), there are errors in the Methods and references. The first sentence of the Patients section (under Methods) should read: "GLANCE (natalizumab + glatiramer acetate vs GA alone [given with placebo] ${ }^{17}$...." The link in reference 11 should read: http://www.ema.europa.eu/ema/index.jsp?curl=pages/medicines/ human/medicines/000603/human_med_001119.jsp\&mid=WC0b01ac058001d124. The authors regret the errors.

Prospective randomized trial of venous angioplasty in MS (PREMiSe)

In the article "Prospective randomized trial of venous angioplasty in MS (PREMiSe)" by A.H. Siddiqui et al. (Neurology ${ }^{\circledR}$ 2014;83:441-449), there is an error in table 3. The first column, fifth row should read: "T1-LV absolute change." The authors regret the error. 


\title{
Neurology
}

\author{
Spice, pot, and stroke \\ Peter Alan Barber, John C.M. Brust and Neil E. Anderson \\ Neurology 2014;83;772 \\ DOI 10.1212/WNL.0000000000000722
}

This information is current as of August 18, 2014

\begin{tabular}{|c|c|}
\hline $\begin{array}{l}\text { Updated Information \& } \\
\text { Services }\end{array}$ & $\begin{array}{l}\text { including high resolution figures, can be found at: } \\
\text { http://n.neurology.org/content/83/8/772.1.full }\end{array}$ \\
\hline References & $\begin{array}{l}\text { This article cites } 3 \text { articles, } 3 \text { of which you can access for free at: } \\
\text { http://n.neurology.org/content/83/8/772.1.full\#ref-list-1 }\end{array}$ \\
\hline Citations & $\begin{array}{l}\text { This article has been cited by } 1 \text { HighWire-hosted articles: } \\
\text { http://n.neurology.org/content/83/8/772.1.full\#\#otherarticles }\end{array}$ \\
\hline Permissions \& Licensing & $\begin{array}{l}\text { Information about reproducing this article in parts (figures,tables) or in } \\
\text { its entirety can be found online at: } \\
\text { http://www.neurology.org/about/about_the_journal\#permissions }\end{array}$ \\
\hline Reprints & $\begin{array}{l}\text { Information about ordering reprints can be found online: } \\
\text { http://n.neurology.org/subscribers/advertise }\end{array}$ \\
\hline
\end{tabular}

Neurology ${ }^{\circledR}$ is the official journal of the American Academy of Neurology. Published continuously since 1951, it is now a weekly with 48 issues per year. Copyright @ 2014 American Academy of Neurology. All rights reserved. Print ISSN: 0028-3878. Online ISSN: 1526-632X.

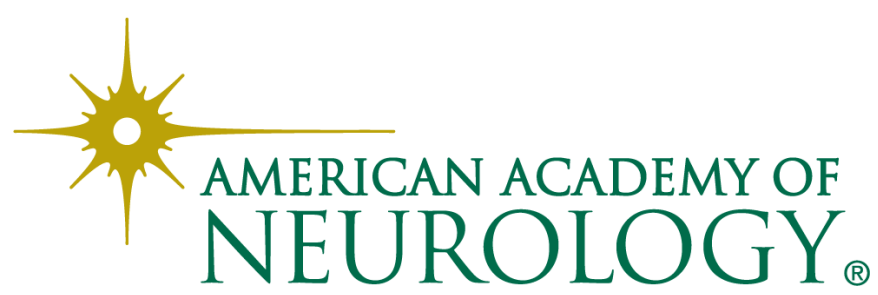

